\title{
Active Volcanoes of Kamchatka and Northern Kurils in 2005
}

\author{
O. A. Girina, A. G. Manevich, N. A. Malik, D. V. Mel'nikov, \\ S. V. Ushakov, Yu. V. Demyanchuk, and L. V. Kotenko \\ Institute of Volcanology and Seismology, Far East Division, Russian Academy of Sciences, \\ Petropavlovsk-Kamchatskii, 683006 Russia \\ Received August 22, 2006
}

\begin{abstract}
In 2005, six major eruptions of four Kamchatka volcanoes (Bezymyannyi, Klyuchevskoy, Shiveluch, and Karymskii) occurred and the Avachinskii, Mutnovskii, and Gorelyi Kamchatka volcanoes and the Ebeko and Chikurachki volcanoes in northern Kurils were in a state of increased activity. Owing to a close collaboration between the KVERT project, Elizovo airport meteorological center, and volcanic ash advisory centers in Tokyo, Anchorage, and Washington (Tokyo, Anchorage, and Washington VAACs), all necessary measures for safe airplane flights near Kamchatka were taken and fatal accidents related to volcanic activity did not occur.
\end{abstract}

DOI: $10.1134 / \mathrm{S} 0742046307040021$

\section{INTRODUCTION}

Active volcanoes in Kamchatka and northern Kurils are subject to complex monitoring within the scope of the KVERT project $[4,6]$ in a close collaboration between the Institute of Volcanology and Seismology (IViS DVO RAN), the Kamchatka Branch of the Geophysical Service (KF GS RAN), and the Alaskan Volcanological Observatory (AVO, USA). The monitoring of the volcanoes includes an analysis of seismic activity performed by KF GS RAN, visual and video observations of the Klyuchevskoy, Shiveluch, and Bezymyannyi volcanoes (KF GS RAN), field work in the regions of active volcanoes aimed at studying the processes that occur before and during eruptions, and the processing of satellite data in order to reveal thermal anomalies, ash ejections, and ash and steam-gas plumes.

In 2005 six strong eruptions of four Kamchatka volcanoes (Bezymyannyi, Klyuchevskoy, Shiveluch, and Karymskii) occurred and the Avachinskii, Mutnovskii, and Gorelyi volcanoes in Kamchatka, as well as the Ebeko and Chikurachki volcanoes in the northern Kurils, were in a state of increased activity. The times of these events are indicated in this paper in Greenwich time (UTC) (local time = Greenwich time $+12 \mathrm{~h}$ in winter or $+13 \mathrm{~h}$ in summer).

\section{KAMCHATKA}

Shiveluch Volcano is the most northern, and one of the most active volcanoes, in Kamchatka. The current cycle of its eruptive activity began in 1980 . Two eruptions related to the growth of its lava dome occurred in 2005: on February 27 the largest explosive eruption occurred since the paroxysm of 1964, a small explosive event accompanied by a landslide occurred on September 22 as well.
From January to February of 2005, volcano seismicity was above the background level and surface earthquakes and spasmodic volcanic tremor were registered every day. However, a clearly defined seismic preparation before the eruptive event of February 27, 2005, was not observed in the region of the Molodoi Shiveluch Volcano. Luminosity of individual dome areas was observed between February 20 and 22, which indicated that the extrusive process had intensified. This phenomenon also was linked with an increase in the number of isolated hot blocks and avalanches from the dome.

Strong explosive activity of the volcano began at 0625 UTC on February 27 (according to the KF GS RAN seismic data). Seismicity increased at 1150 UTC on that day, and the SVL seismic station, located $8 \mathrm{~km}$ from the lava dome, stopped operating at approximately the same time. At the Klyuchi seismic station, it was not possible to detect seismic signals related to eruptive events at the Shiveluch Volcano because of the high activity of the Klyuchevskoy Volcano. The eruption duration, estimated by KF GS RAN based on the seismic data from remote (e.g., up to $200 \mathrm{~km}$ from the volcano) seismic stations, was about $6 \mathrm{~h} 35 \mathrm{~min}$ (from 0625 to 1300 UTC on February 27).

According to the information from pilots flying on international air routes near Kamchatka, the height of the eruptive column was approximately $8.5 \mathrm{~km}$ above sea level (asl) at 0745 UTC on February 27. As the result of intense cyclonic activity, an eruptive cloud moved westward from the volcano, although ash also precipitated in Klyuchi that day. The depth of snow contaminated with ash was $2-3 \mathrm{~cm}$ in this region. According to the data of Elizovo AMTs, ash also precipitated in Ust'-Khairyuzovo (on the western Kamchatka coast) from 2140 UTC on February 27 to 1940 UTC on February 28. The Ust'-Khairyuzovo airport was closed 


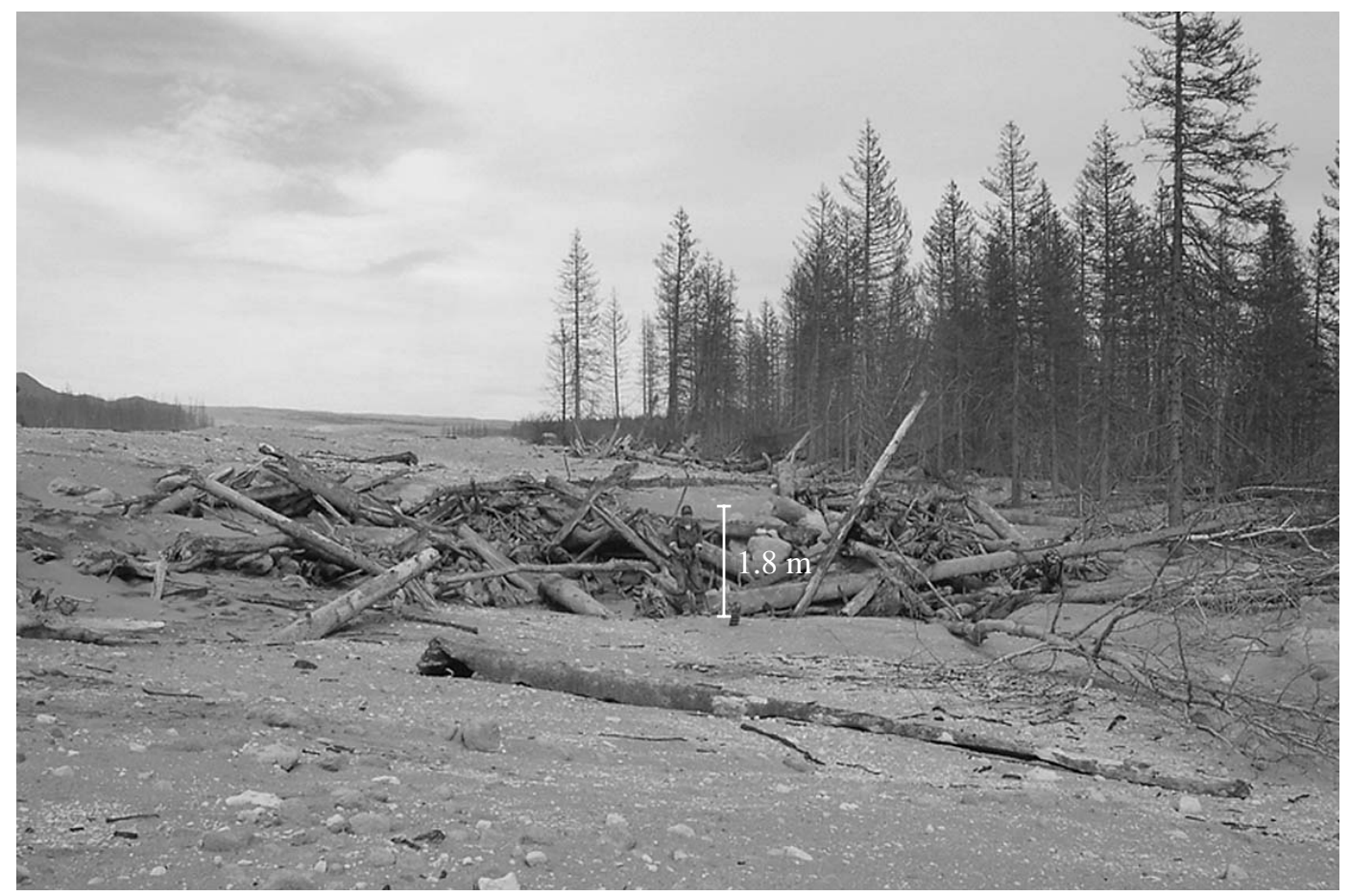

Fig. 1. Pyroclastic flow deposits of Shiveluch Volcano on February 27, 2005 (photographed by O.A. Girina).

during this period. A thin layer of fine reddish ash covered snow in the settlement. According to a hunter, the thickness of wine-colored ash together with snow was $1 \mathrm{~cm}$ at a distance of $20 \mathrm{~km}$ from Verkhnee Khairyuzovo. According to the data of the Kamchatka Hydrometeorological Center (KHC) the thickness of pure ash there was $2-3 \mathrm{~cm}$ in the region of Lake Dvukhyurtochnoe. The total area covered with tephra was 25 thousand $\mathrm{km}^{2}$ [2]. Unfortunately, dense clouds above the peninsula made it impossible to continuously trace the volcanic eruption.

At 1656 UTC on February 28, a thermal anomaly of 45 pixels was observed on a NOAA-16 AVHRR satellite photograph in the region of the volcano [2]. The anomaly was related to deposits from a pyroclastic flow over a large area, which filled the Baidarnaya River Valley on the southwestern flank of the volcano. The extent of this flow was estimated from TERRA MODIS and ASTER satellite photographs and was subsequently verified during field studies performed in July 2005 with the use of GPS $(28 \mathrm{~km})$ [5]. High flow gas-saturation and temperature $\left(402^{\circ} \mathrm{C}\right.$ at a depth of $\left.167 \mathrm{~cm}\right)$ were registered in March when the flow deposits were investigated. The in situ density of hot deposits in one of the branches of pyroclastic flow (with a thickness ranging from 0.5 to $5-10 \mathrm{~m}$ ) varied from 1.65 to $1.79 \mathrm{~g} \mathrm{~cm}^{-3}$ at a depth of 4-7 cm from the surface within a distance of several kilometers from the front-most portion of the flow. In the widest part of the flow, before it branched, the thickness of the deposits was about $20 \mathrm{~m}$, the deposits were gas-saturated, and their in situ density was
$1.48-1.50 \mathrm{~g} \mathrm{~cm}^{-3}$. Numerous depressions caused by secondary phreatic explosions were observed on the surface of the flow. The flow destroyed a forested area measuring more than $10 \mathrm{~km}^{2}$; many trees were partially buried in the flow deposits, and other trees remained at the surface of the flow (Fig. 1). Deposits from pyroclastic waves were located on the flow surface at the flow front and between the flow tongues. The thickness and volume of the pyroclastic flow deposits were about $21 \mathrm{~km}^{2}$ and $0.2 \mathrm{~km}^{3}$, respectively [5].

Instrumental measurements performed on March 5 in Klyuchi (45 km from the volcano) indicated that the visible height of the lave dome decreased by approximately $130 \mathrm{~m}$ as a result of the eruption. A new extrusive block was noted in the western portion of the dome immediately after the eruption. Activity at the dome consisted primarily of steam and gas, along with a small amount of ash, in March and April. By the beginning of April, the height of the eastern and growing western dome areas became approximately identical. Subsequently, the growth of the dome decelerated slightly, and relatively rare explosions occurred to a height of 7-8 km asl. The first ash ejection after the February eruption, with a height of $4 \mathrm{~km}$ asl, was registered on June 1. Dome block failures, accompanied by red-hot avalanches, were rare in May, June, and August but were almost constant in July. Volcanologists who were working on the flank of the volcano observed continuous red-hot avalanches and the formation of an eruptive column to a height of $3-5 \mathrm{~km}$ asl for about 40 min from 1725 UTC on June 30 . The most powerful 


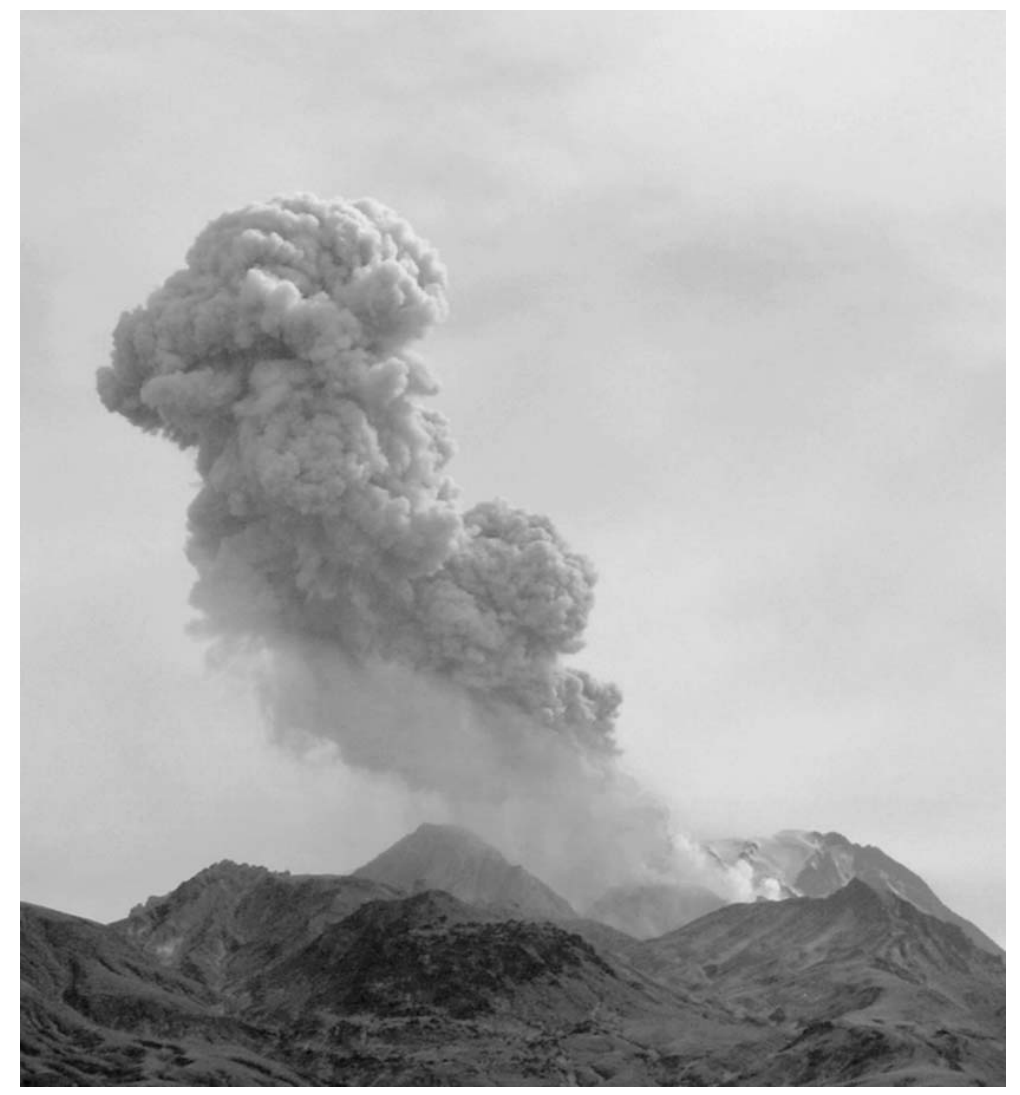

Fig. 2. Ash explosion of Shiveluch Volcano to a height of 7.5 asl on July 7, 2005 (photographed by O.A. Girina).

of these avalanches extended to within $4.5 \mathrm{~km}$ from the bottom of the dome. Secondary phreatic explosions on the pyroclastic flow were also often observed in June and July. A seismic event with a duration of 11 min was registered at 1240 UTC on July 7 at the Klyuchi seismic station, which is located at a distance of $45 \mathrm{~km}$ from the volcano. According to volcanologists who were working on the flank of the volcano, the height of the ash explosion was approximately $7.5 \mathrm{~km}$ asl (Fig. 2). We should note that volcanic activity increased in July: ash ejections and red-hot avalanches were observed almost every day, explosive ash reached a height of $7.5 \mathrm{~km}$ asl, and ash caused by red-hot avalanches reached a height of $4.5 \mathrm{~km}$ asl. Ash plumes mainly propagated westward.

A new volcanic eruption occurred at 0515 UTC on September 22. This eruption was related to the gravitational failure of a portion of the viscous lava block in the southwestern part of the dome, which was probably provoked by explosive volcanic activity. According to the KF GS RAN data, a volcanic tremor with $A / T_{\max }$ from 0.11 to $0.22 \mu \mathrm{m} \mathrm{s}^{-1}$ was registered in the region of the volcano October 20-21. During the eruption, the ash column reached a height of $7.5 \mathrm{~km}$ asl according to the seismic and satellite data. According to visual data from seismologists who were working on the southwestern crest above the Baidarnaya River valley at a distance of approximately $9 \mathrm{~km}$ from the lava dome, ash precipitated in their camp from 0600 to 0800 UTC on September 22. According to satellite data, the ash plume extended $480 \mathrm{~km}$ southeastward from the volcano. According to Yu.V. Demyanchuk's information, the axis of the ash fall passed slightly west of the Sukhaya Khapitsa River. On the Klyuchevskoy Volcano flank at a distance of $60 \mathrm{~km}$ from the Shiveluch Volcano, the ash thickness reached $0.3-0.5 \mathrm{~cm}$, and the amount of the precipitated ash was about $200 \mathrm{~g} \mathrm{~m}^{-2}$. A pyroclastic flow up to $20 \mathrm{~km}$ in extension and with a volume of $0.01 \mathrm{~km}^{3}$ was formed on the southwestern flank of the volcano (Fig. 3) [5]. After the volcanic eruption, viscous lava continued pressing on the dome during September-December 2005 and was sometimes accompanied by small red-hot avalanches. From October to December 2005, volcanic activity gradually decreased.

Klyuchevskoy Volcano is the highest active volcano in Eurasia and one of the most productive volcanoes in the world. A strong explosive eruption of the volcano occurred from January to April 2005; subsequently, the volcano was in a moderately active state. Previous Strombolian-Vulcanian activity was observed from September 2003 to January 2004. Ash ejections to a height of 5-7 km asl and the formation of a slag cone within the crater were observed at that time. Luminos- 


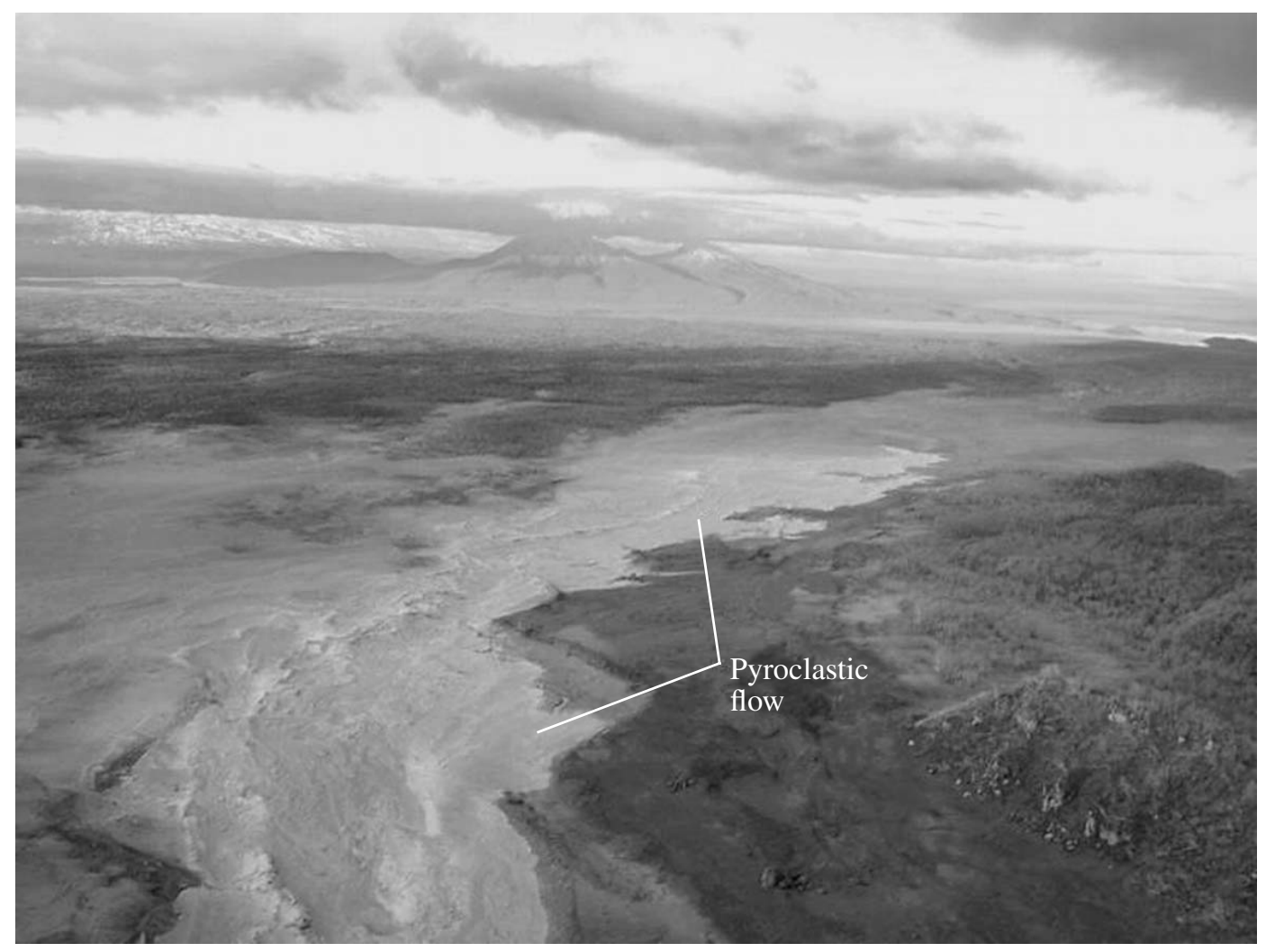

Fig. 3. Pyroclastic flow deposits of Shiveluch Volcano on September 22 (photographed by V.V. Yashchuk).

ity above the volcano, caused by filling of the crater with lava and by Strombolian activity, was observed for two weeks from the 11th to the 26th of January, 2004.

Active seismic preparation was registered before the eruption in 2005. From the end of October 2004 to January 11,2005 , seismicity of the volcano was mostly at the background level. Surface earthquakes with a magnitude of 1.0-2.2 were consistently registered from January 6 until the end of the explosive eruption in the volcanic edifice. On January 12, 2005, the seismicity of the volcano exceeded the background level. Spasmodic volcanic tremor was interrupted at that time and became constant from January 14. From January 15, recording of earthquakes from a depth of $30 \mathrm{~km}$ ceased, and a thermal anomaly was observed above the volcanic crater in the satellite photographs. Up until January 16,2005 , only steam and gas activity of differing intensities, with an average height of the steam-and-gas column of up to $5 \mathrm{~km}$ asl, was observed on the volcano. From January 16, the height of the fumarolic column increased to $6 \mathrm{~km}$ asl, and ash was observed in this column.

Luminosity above the crater, as it began to fill with lava, was first registered on January 16, when the culmination stage of the volcanic eruption began. Luminosity was observed for eight days, but the beginning of Strombolian-Vulcanian activity was registered only on January 21 . That day, ash plumes extending up to $40 \mathrm{~km}$ northeastward from the volcano were registered in satellite photographs. The effusive phase of the eruption began on January 31, as lava flowed along the Krestovskii barranco. According to information from loggers, a mudflow passed along the Kruten'kaya River almost to the Klyuchi-Apakhonchich road, which they observed at a distance of $6 \mathrm{~km}$ southeast of Klyuchi. The mudflow front, with a height of up to several meters, carried mud, huge stones, and trees. On February 1 , the members of the Levinson-Lessing Kamchatka Volcanological Station investigated the river bed. The bed depth was about $5 \mathrm{~m}$. The area on both sides of the bed was covered with stones and mud at a distance of up to $100 \mathrm{~m}$. Mud was also observed on tree trunks at a height of up to $1.5 \mathrm{~m}$. Thus, the mudflow thickness was about $6.5 \mathrm{~m}$. These lava and mud flows were registered by KVERT members and also on TERRA MODIS satellite photographs beginning from 0023 UTC on February 1 (Fig. 4).

The volcanic eruption intensified from February to March as lava flowed along the Krestovskii barranco on February 2 (Fig. 5a). Due to the lava flow, a thermal anomaly on satellite photographs increased to 20 pixels and subsequently varied from 15 to 60 pixel. During February, red-hot bombs were ejected to a height of up to $300 \mathrm{~m}$ above the crater edge at an interval of 15-30 s. Vulcanian activity was evident starting on February 6. Steam and gas ejections from the summit crater with 


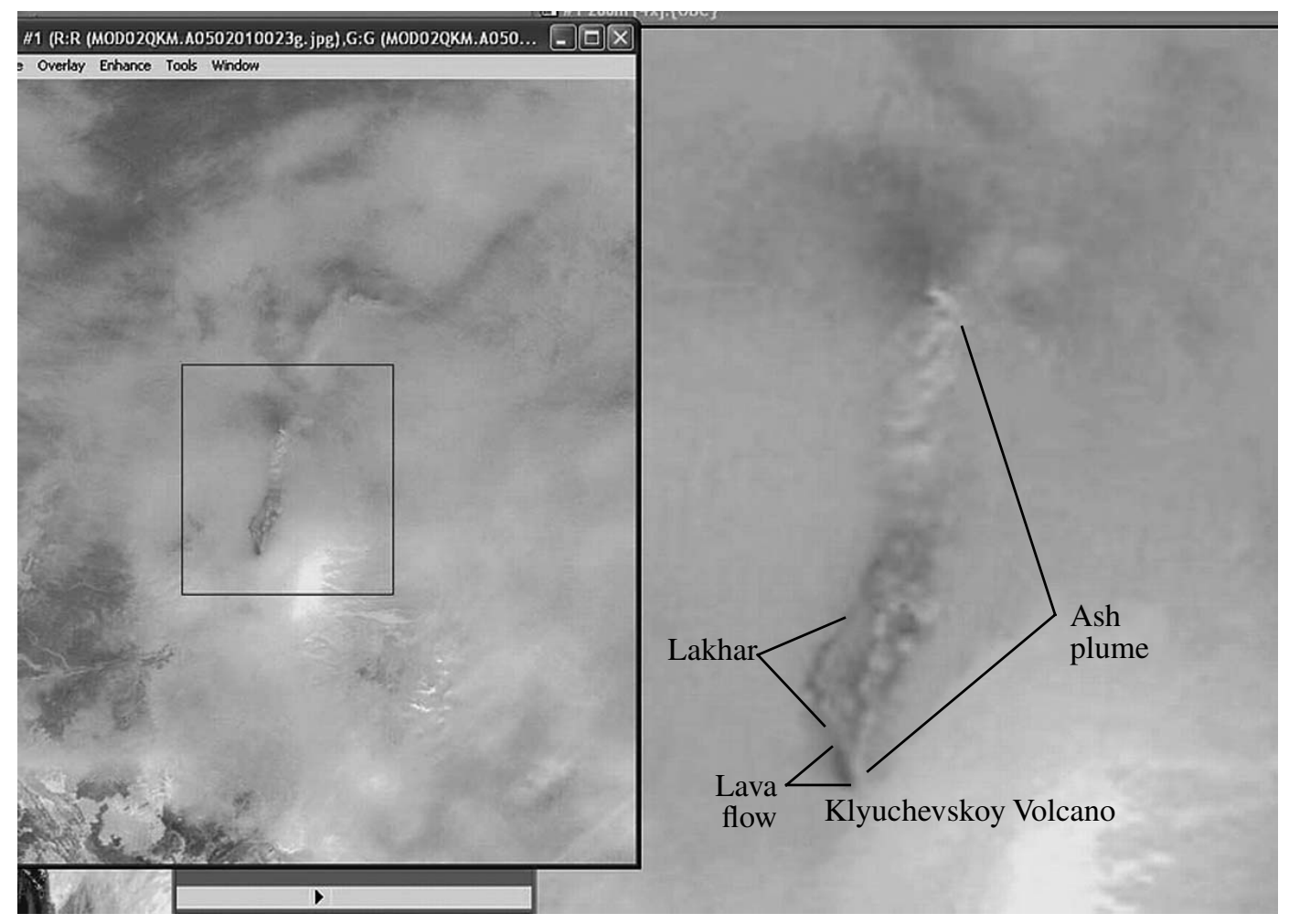

Fig. 4. Ash plume and lava and mud flows on the slope of Klyuchevskoy Volcano at 0023 UTC on February 1, 2005 (the TERRA MODIS photograph). The data were processed by O. Girina and D. Mel'nikov.

differing amounts of ash, which reached heights of up to $6-7.5 \mathrm{~km}$ asl, were observed almost every day, as well as ash plumes extending up to $50-250 \mathrm{~km}$ from the volcano. Powerful phreatic explosions reaching heights of up to 7-8 km asl occurred in the Krestovskii barranco as a result of the intrusion of lava flow into glaciers (Fig. 5b). Ash plumes mostly propagated northeastward and northwestward. A slag cone was observed in the volcanic crater which was higher than the crater edge by approximately $100 \mathrm{~m}$. When members of IViS DVO RAN flew around the volcano on February 16, they observed that the lava flow descended to a height of $2.5 \mathrm{~km}$ asl and the mudflow extension was about $27 \mathrm{~km}$. Powerful Strombolian activity of the volcano was observed from the end of February to the middle of March as the height of red-hot bomb ejections reached $1 \mathrm{~km}$ above the crater. From March 15, lava moved along the Krestovskii barranco and the volcanic slope in several branches. On March 23-24, ash was ejected to a height of $8.8 \mathrm{~km}$ asl. Ash plumes extended mostly northward and northwestward from the volcano within distances of up to $250-350 \mathrm{~km}$ (up to $600 \mathrm{~km}$ on March 23 and 24).

From March 13, the amplitude of continuous volcanic tremors began to decrease. Up to April 3, ash columns ascended from the volcanic crater to a height of $6.0-7.5 \mathrm{~km}$ asl. About eight ash falls, the strongest of which occurred in Klyuchi on March 23-24, were observed in February and March in Klyuchi and Kozyrevsk, the closest settlements to the volcano.

Volcanic activity gradually decreased at the end of March and in April, volcanic seismicity decreased to the background level on April 29, and the explosiveeffusive eruption of 2005 came to the end.

During a flight around the volcanic crater in August 2005 , it was elucidated that a slag cone that had formed during the last eruption occupied almost the entire crater (Fig. 6).

Weak bursts of volcanic activity were registered in July and September 2005. Surface earthquakes were registered in the volcanic edifice below the central crater. According to volcanologists who worked in the Bezymyannyi Volcano region, a small ejection of ash from the Klyuchevskoy Volcano crater rising to a height of about $100 \mathrm{~m}$ occurred at 2222 UTC on July 21 . This ejection was possibly caused by the beginning of the destruction of the slag cone within the crater which was related to magma outflow along the crater channel. According to the data from climbers who reached the volcanic summit in the summer of 2006, the slag cone was already absent in the crater. From June to November primarily fumarolic activity was observed, which was accompanied by the ascent of a steam and gas column to a height of up to 5-6 km asl. A weak thermal anomaly near the volcanic summit was occasionally registered in July-October. 

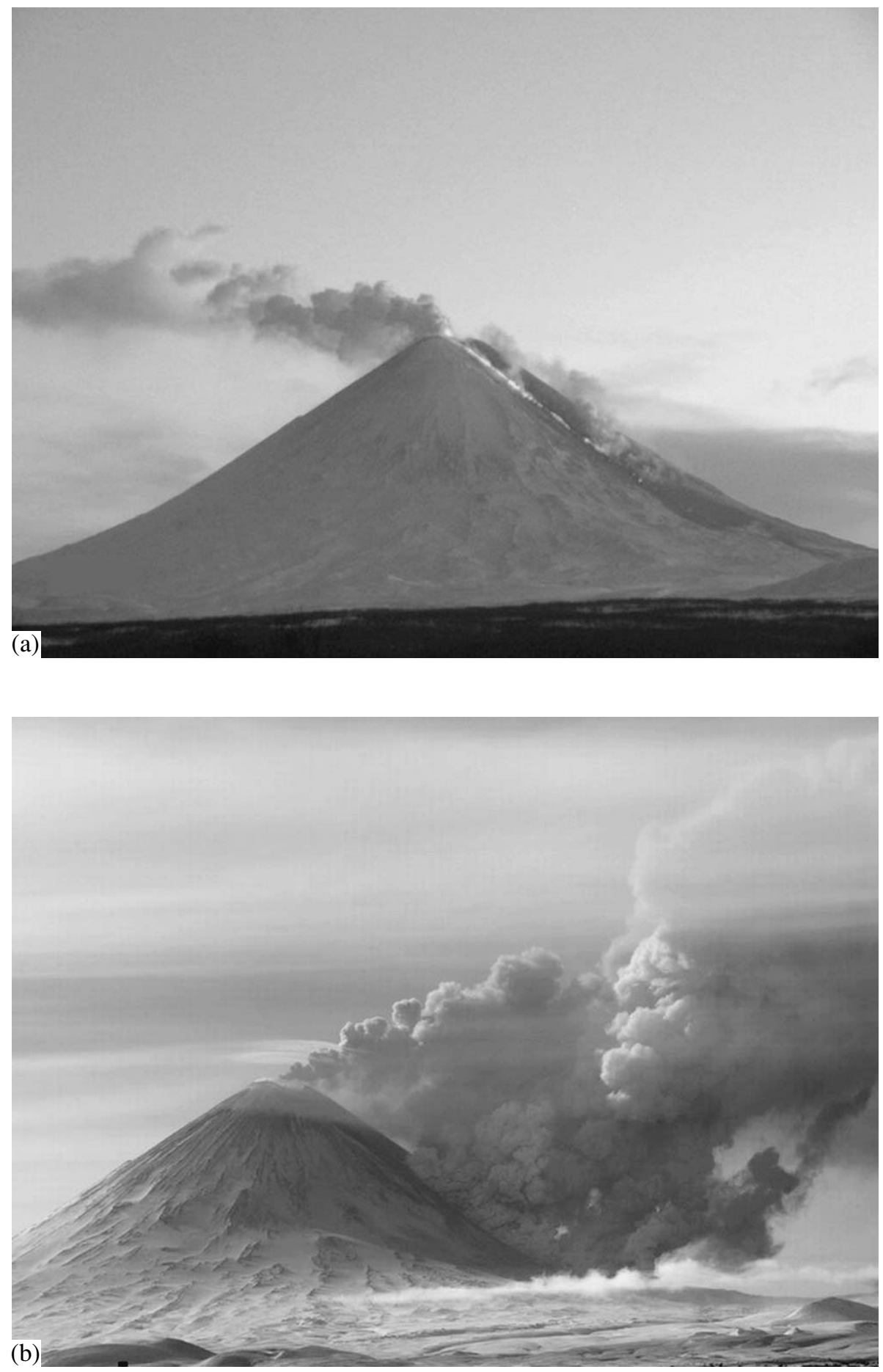

Fig. 5. Activity of Klyuchevskoy Volcano: (a) lava flow and (b) phreatic explosions in the Krestovskii barranco (photographed by V.G. Ushakov).

Bezymyannyi Volcano, one of the most active volcanoes of Kamchatka, is located in the central part of the Klyuchevskoy volcanic group. Two explosive eruptions of this volcano took place in 2005, and both eruptions were predicted by KVERT (KF GS RAN) members based on seismic and satellite data.
The explosive eruption of the volcano began at 0802 UTC on January $11[1,7]$. According to the seismic data, the most active eruption phase, accompanied by an ash cloud ascent to a height of $8-10 \mathrm{~km}$ asl, took place from 0802 to 0845 UTC. According to the NOAA AVHRR, GOES, and MODIS (TERRA and AQUA) 


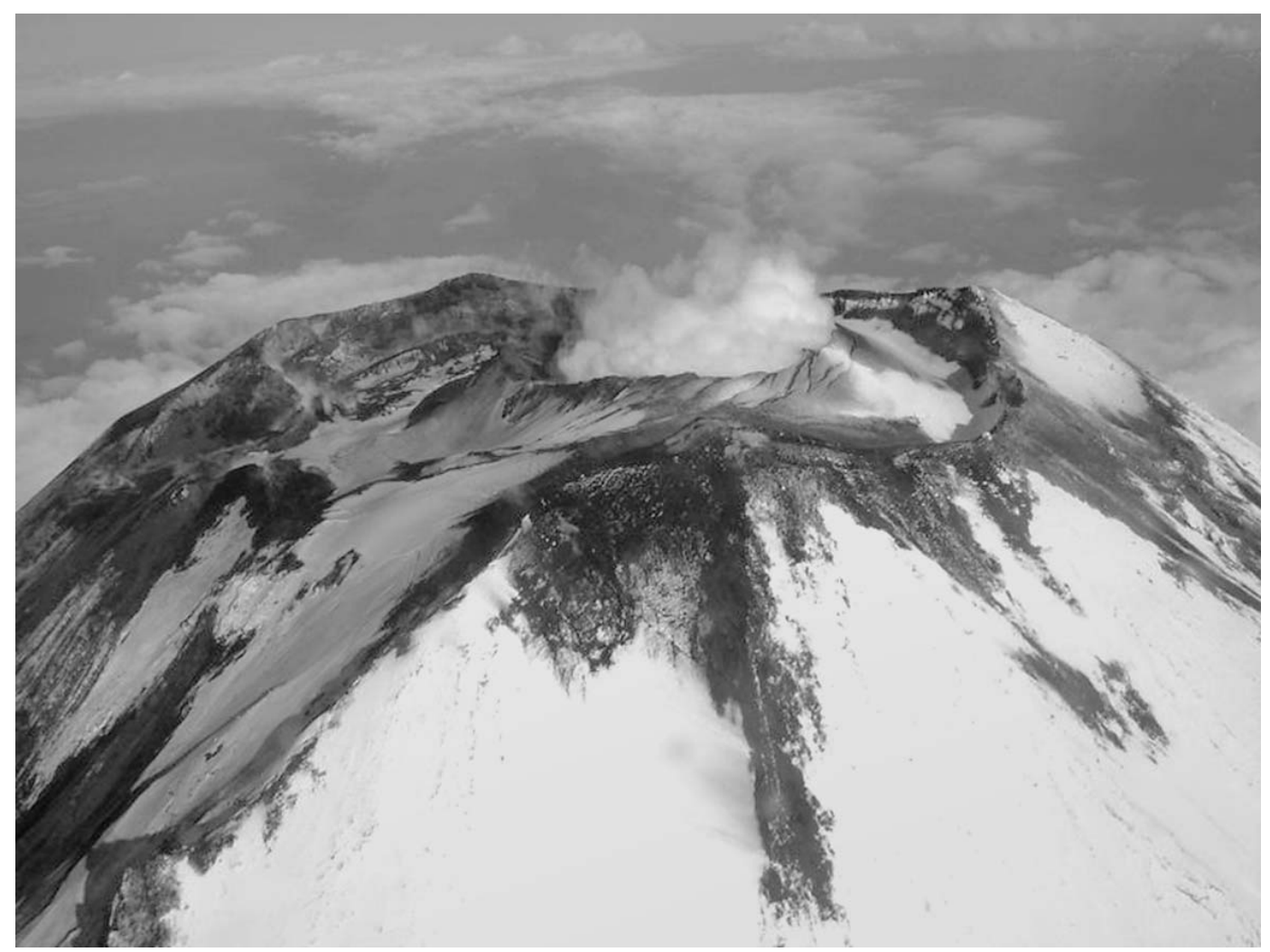

Fig. 6. State of the summit crater of Klyuchevskoy Volcano on August 21, 2005 (photographed by S. Rose).

satellite photographs, ash clouds moved west-southwestward from the volcano within a distance of several hundred kilometers. The area of ash deposits on Kamchatka was about $5000 \mathrm{~km}^{2}$. The tephra thickness was $0.5 \mathrm{~cm}$ near the Kamchatka River crossing and $0.1 \mathrm{~cm}$ in the region of the bridge across the Bil'chenok River. A helicopter flight around the volcano on July 27 indicated that two merged craters - the central crater of about $300 \mathrm{~m}$ in diameter and $200 \mathrm{~m}$ in depth, and a small crater south-southwest of the central one-were formed at the dome summit during the eruption. Coarse-clastic tephra deposits (andesite lava fragments of 2-4 to $30-100 \mathrm{~cm}$ across) covered the southeastern sector of the volcano with an area of more than $120 \mathrm{~km}^{2}$. On the south-southeastern flank of the volcano, deposits from an ash-block pyroclastic flow, which extended for a distance of $8 \mathrm{~km}$, as well as pyroclastic waves, which were transformed into ash flows during their progress, were formed as a result of the eruption. The total volume of pyroclastic deposits was about $0.1 \mathrm{~km}^{3}$. Two lava flows were pressed onto the western and northwestern dome slopes at the final stage of the eruption (Fig. 7a).

The next explosive eruption of the volcano occurred from 1200 to 1315 UTC on November 30. Starting on November 11, volcanic seismicity began to slowly increase. Seismic signals accompanying the fall of redhot avalanches were registered, and volcanic tremor appeared on November 29. The KVERT (KF GS RAN) members predicted an explosive eruption of the volcano based on the seismic data. Visual observations of explosive volcanic activity were absent because a strong cyclone occurred at Kamchatka during that time. Gusts carried a small amount of ash to Kozyrevsk. A local ash cloud, several tens of kilometers across, moved westward from the volcano toward the Sea of Okhotsk at a height of about $6 \mathrm{~km}$ asl and was potentially hazardous for aircraft on Russian and international air routes. Since the weather was bad in Kamchatka, aircraft could not land at the Elizovo airfield and instead landed in continental Russia. This circumstance, and the timely information from KVERT to the airport meteorological center (AMC), allowed aircraft to avoid ash clouds.

During a flight around the volcano on April 1, 2006, a new lava flow and a fissure of more than $300 \mathrm{~m}$ in length were found on the western slope of the dome. This fissure passed approximately along the boundary between the lava flows which occurred in 2004 and 2005 (Fig. 7b). A large extrusive block was observed at the dome center. The formation of this fissure was possibly related to the eruptive event of November 30, 2005.

Primarily weak fumarolic activity of the dome was observed during 2005 between explosive eruptions, and 

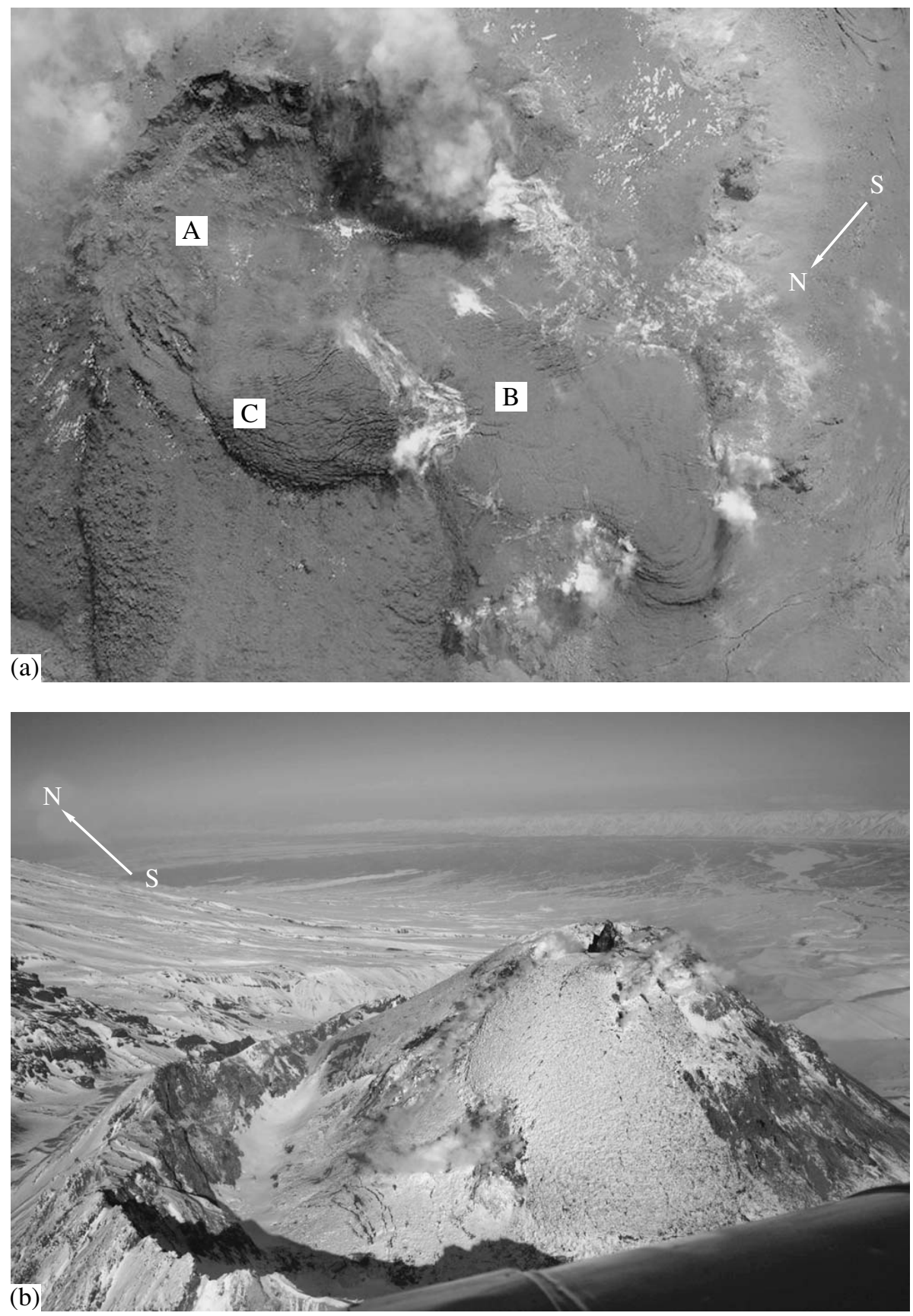

Fig. 7. Lava dome of Bezymyannyi Volcano. (a) August 20, 2005; (A) explosive crater, (B) less viscous lava flow, and (C) viscous lava flow (photographed by S. Rose). (b) April 1, 2006 (photographed by Yu.V. Demyanchuk).

a steam and gas column occasionally reached a height of $1200 \mathrm{~m}$ above the dome crest. Steam and gas plumes generally extended eastward, southeastward, and westward from the volcano.

Karymskii Volcano was in a state of StrombolianVulcanian activity in 2005. Since the volcano is located at a large distance from settlements, its state was mainly assessed based on data from the Karymskaya seismic station (KRY) operated by KF GS RAN. During this year, the seismic activity of the volcano was unstable as three sharp (on April 13, June 29, and August 30) and two weaker (on April 25 and May 14) increases in activity were observed.

Visual observations of the volcano revealed the following types of activity: (a) the steam and gas type, with emissions with differing, but small, amounts of ash; (b) the Strombolian type, in which ash ejections to a height of 200-500 $\mathrm{m}$ above the crater occurred at 


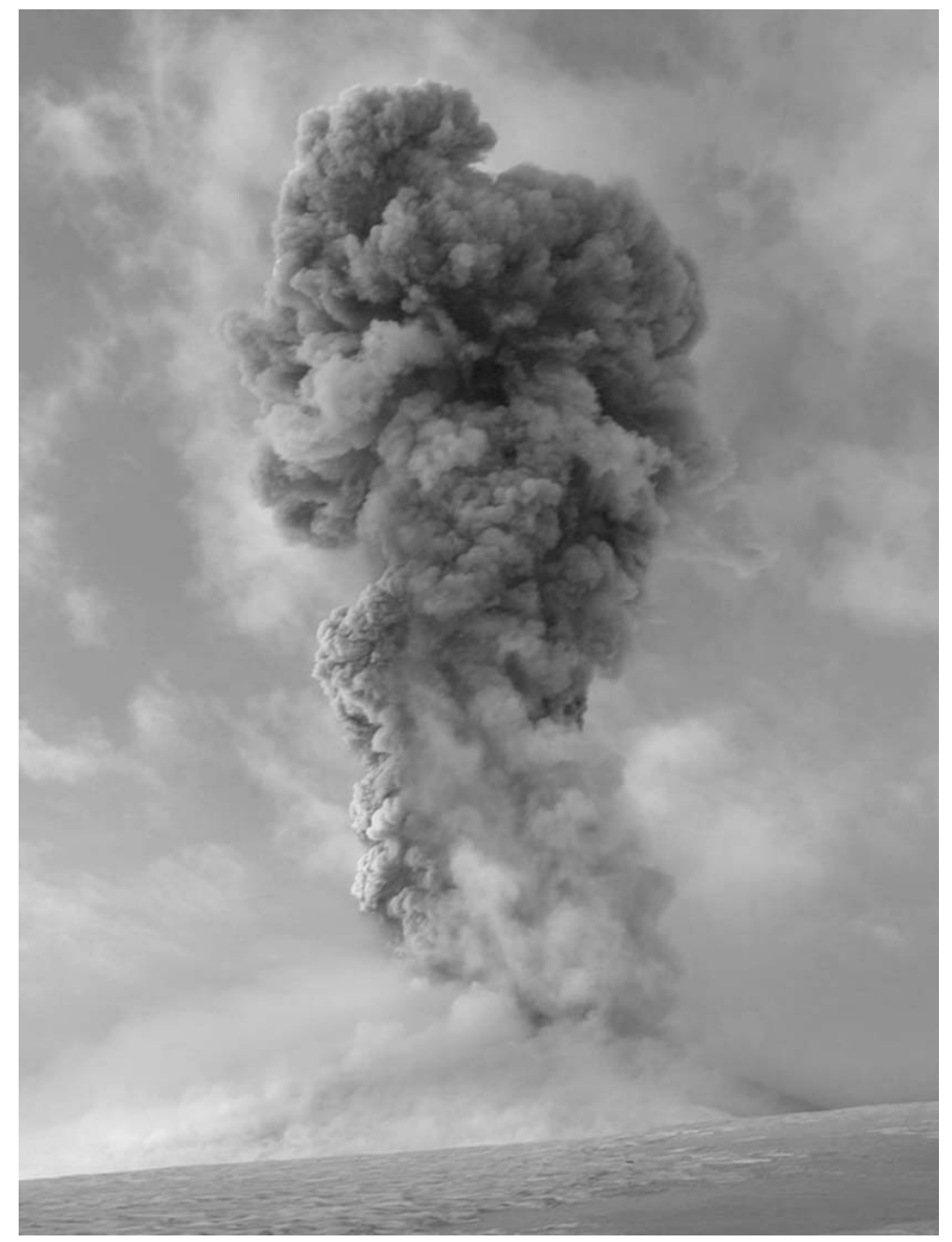

Fig. 8. Explosive activity of Karymskii Volcano on December 22, 2005 (photographed by A.G. Manevich).

intervals of 3-20 min; and (c) the Vulcanian type, with powerful ash ejections to a height of up to $5 \mathrm{~km}$ asl, before which pauses in the eruptive and seismic activity were usually observed. Ejections were accompanied by airborne shock waves and bombs widely scattered over the cone slopes (Fig. 8).

As a result of the explosions, ash plumes were formed, the density and extension of which depended on the power of ash ejections and wind strength. Ash deposits were observed mostly in the $90^{\circ}-270^{\circ}$ azimuthal sector within a distance of up to several tens of kilometers from the volcano.

During fieldwork performed from April 20 to May 3, a pyroclastic flow with a length of about $1.6 \mathrm{~km}$ and a width of 150-200 $\mathrm{m}$ across its frontal portion was discovered in the southwestern part of the cone. An analysis of the volcanic seismicity allows us to assume that the flow was formed during the activation of the volcano on April 13.

At the end of September, a lava dome was discovered in the volcanic crater (http://www.ksc- net.ru/ivs/kvert/current/krm/new.html). By the end of October, the dome filled the major portion of the crater. To all appearances, this dome was often partially destroyed as a result of powerful explosions, which is confirmed by pumice fragments measuring up to 10$15 \mathrm{~cm}$ across which were found in December on snow located 3-4 km from the crater. Most likely, a new dome was observed in the volcanic crater on December 18. Judging by the dome morphology, this dome was less viscous than the previously destroyed cone.

The satellite photographs showed an almost continuous 13-pixel thermal anomaly in the region of the volcano in 2005. Most likely, the small value of the thermal anomaly was primarily caused by the fact that the satellite photographs were obtained during explosive, and especially, the Strombolian, activity of the volcano. The extension of the thermal anomaly in the region of the crater makes it possible to distinguish three phases of volcanic activation in 2005 , which occurred in the middle of April, the middle of July, and the end of August, which is in good agreement with the data of the 
seismic and visual observations. This volcanic eruption is presently continuing.

Avachinskii Volcano was in a state of fumarolic activity in 2005. The number of isolated seismic events and their series increased twice during the year. The first increase occurred in the middle of November of 2004 and continued until February of 2005. Weak earthquakes, with the magnitude less than 1.0, occurred primarily in the volcanic edifice, or at a depth of up to $0.5 \mathrm{~km}$; the number of earthquakes was not more than nine per day. A following increase in seismicity was registered during November 15-28.

A thermal anomaly in the region of the Avachinskii volcanic crater was registered in satellite photographs on November 7, 21, 22, and 29.

In 2005, the fumarolic activity of the volcano was low. In February and March, the height of the steam and gas column was not more than $600 \mathrm{~m}$ above the crater, with an increase in seismicity. Columns of fumarolic gases reaching a height of $700 \mathrm{~m}$ were observed in July and September. The usual height of these columns was not more than 100-300 m. The temperature of the fumarole operating at the western edge of the crater was not higher than $200^{\circ} \mathrm{C}$ during the year.

Mutnovskii and Gorelyi volcanoes were in a state of weak activity in 2005. The seismicity of these volcanoes was generally no higher than the background level judging by the data from one seismic station located on the flank of the Gorelyi Volcano. Mutnovskii Volcano showed moderate fumarolic activity, and the height of the fumarolic column only occasionally reached 600$700 \mathrm{~m}$ above the edge of the active crater. A weak (12 pixel) thermal anomaly was repeatedly registered on the volcano during the year. The temperature of the fumaroles in the lower fumarolic field of the volcano was about $100^{\circ} \mathrm{C}$. A fumarolic column with a height of $150 \mathrm{~m}$ above the crater edge was only registered on February 13 at the Gorelyi Volcano and the volcano was usually quiescent.

\section{NORTHERN KURILS}

Chikurachki Volcano is the most active volcano in the northern Kurils. In 2005, volcano activation was observed in March and April [3]. On March 1, hunters and navigators informed KVERT that a steam and gas column with a height of up to $400 \mathrm{~m}$ above the crater was observed on the volcano for the first time after a long quiescent period. According to visual observations at the beacon on Cape Podgornyi, weak ash ejections from the volcanic crater occurred on March 10. According to information from pilots, ash deposits were found southeast of the volcano on March 29. Anglers reported that ash ejections were sometimes observed until April 7. KVERT members observed ash plumes March 12 and 23, which extended 40 km northnorthwestward and $70 \mathrm{~km}$ eastward from the volcano, on the TERRA MODIS and NOAA AVHRR satellite photographs. Subsequently, eruptive volcanic activity was not registered visually or on the satellite images.

Ebeko Volcano, located at a distance of $7 \mathrm{~km}$ from Severo-Kuril'sk, is in a state of constant weak activity. From the end of January to April, a steam and gas column reached a height of $600 \mathrm{~m}$ above the crater, and the odor of hydrogen sulfide was sometimes observed in the town [3]. Investigations of the volcano indicated that changes took place in the active crater. New fumaroles appeared, a lake appeared and disappeared, and small ash ejections and weak ash falls were observed at that time in Severo-Kuril'sk and above the Second Kuril Strait. Activation of Ebeko was observed again from July to November.

(1) A new fumarolic field was formed on the outer northeastern slope of the active crater, which was named the July field according to its date of formation. From July to November, the field area considerably increased, the number of powerful fumaroles increased from two to twenty, the intensity of scattered seaming over the field area increased, and gas temperature at the mouth outlet reached $529^{\circ} \mathrm{C}$ in the upper field and increased from $110-123$ to $155^{\circ} \mathrm{C}$ in the lower field. The entire area of this fumarolic field was covered with sulfur sublimates, fissures, and gaps, from which gases intensely released and a strong sulfuric odor was sensed (Fig. 9).

(2) A lake, whose size changed from $15 \times 30 \mathrm{~m}$ on July 16 to $10 \times 15 \mathrm{~m}$ on September 8 , was found in the active crater. The water temperature was approximately $40^{\circ} \mathrm{C}$, and the $\mathrm{pH}$ was 0.8 . The area of heating in the active crater increased. New fumaroles and thermal sites were observed on the inner northeastern wall of this crater, the activity of these fumaroles and sites increased, the fumarole temperature was $480^{\circ} \mathrm{C}$ on September 8, black sulfur deposits were observed near these fumaroles, hydrogen sulfide and chlorine predominated in the composition of gases, and three active fumaroles on the northeaster inner slope and one fumarole on the outer slope were registered on September 15.

(3) An explosive hole of about $1 \mathrm{~m}$ in diameter and $3 \mathrm{~m}$ in depth was formed in the upper reaches of the Lagernyi creek, from the bottom of which steam jets with a temperature of $70-100^{\circ} \mathrm{C}$ ascended; the entire surface around the hole was covered with black mud and sulfur phenocrysts within a radial distance of 7$9 \mathrm{~m}$. By September 29, the hole diameter increased to $1 \times 3 \mathrm{~m}$, and fragments of sulfur with pyrite crystals appeared within a radial distance of $50 \mathrm{~m}$ around this hole.

(4) On September 29, a $70 \times 10 \mathrm{~m}$ thermal site and a hot spring of $3 \mathrm{~m}$ in diameter beneath this site were discovered on the inner eastern wall of the Eastern cirque.

Fumarolic activity of the volcano along with a steam and gas column that ascended to a height of $500 \mathrm{~m}$ and, on November 29 , to $1800 \mathrm{~m}$ above the volcanic crater, 


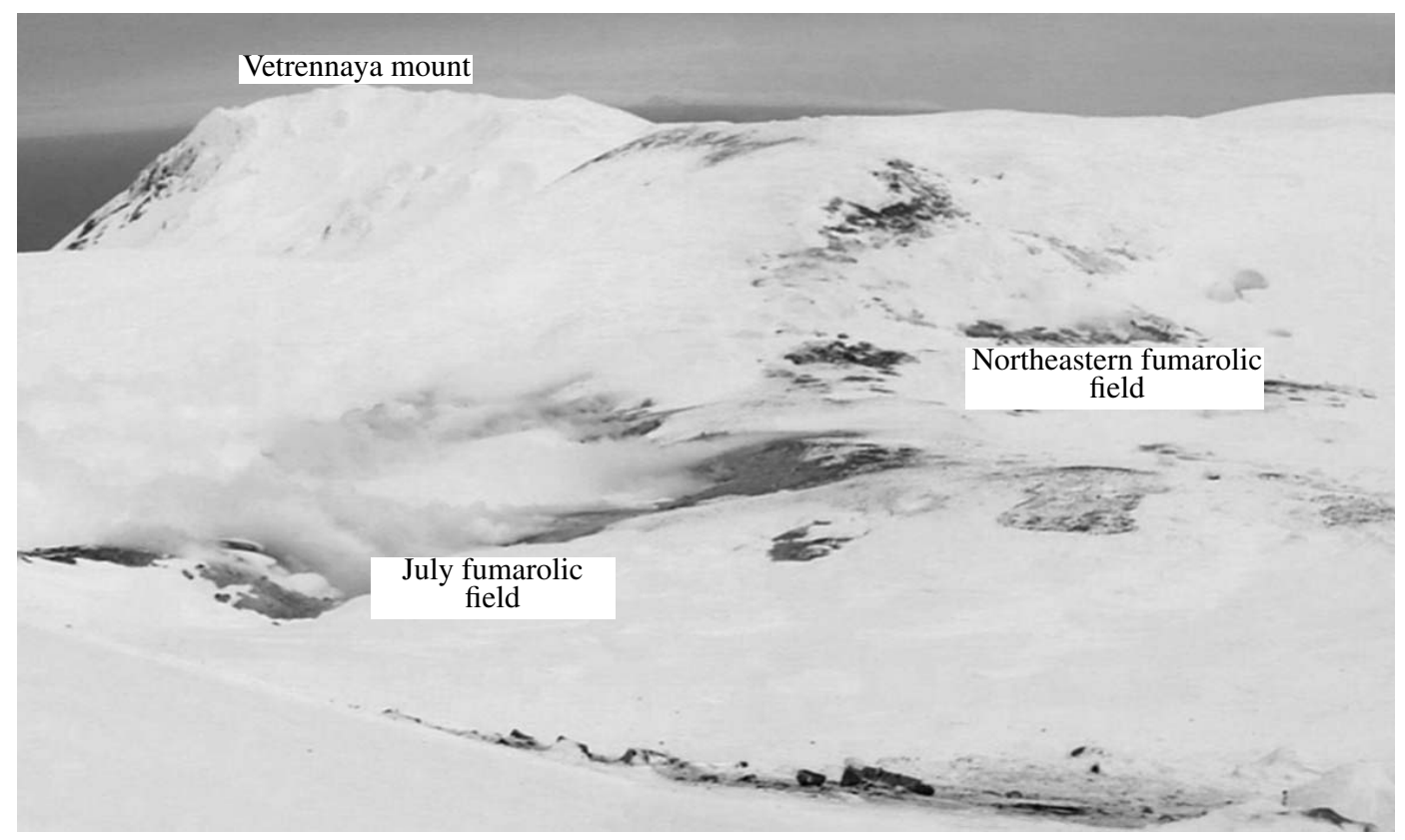

Fig. 9. July fumarolic field on Ebeko Volcano (photographed by L.V. Kotenko).

were observed from July through December. Steam and gas plumes extended east-southeastward and northward from the volcano to a distance of $20 \mathrm{~km}$ on September 15-16. From August through December, the odor of hydrogen sulfide and chlorine, sometimes strong enough to provoke coughing, was observed from three to eight days per month in Severo-Kuril'sk.

\section{CONCLUSIONS}

The Ebeko and Chikurachki volcanoes were in a state of increased activity in the northern Kurils in 2005. The activity of volcanoes in Kamchatka was very high, especially for the volcanoes in the Northern group. Eruptive clouds reached a height of $10 \mathrm{~km}$ asl, and ash plumes which extended several hundred kilometers from the volcanoes were very hazardous for aircraft flying in the region of the peninsula. Owing to close cooperation between the participants in the KVERT project, the meteorological center of the Elizovo airport, and the Tokyo, Anchorage, and Washington VAACs, all necessary measures for safe flights near Kamchatka were taken and fatal accidents related to explosive volcanic activity did not occur.

\section{REFERENCES}

1. Girina, O.A. and Gorbach, N.V., Bezymyannyi Volcano Eruption of January 11, 2005, in Materialy Mezhdunarodnogo simpoziuma po problemam eksplozivnogo vulkanizma (Proc. Int. Symposium on Problems of Explosive Volcanism), Petropavlovsk-Kamchatskii, 2006, pp. 87-97.
2. Girina, O.A., Demyanchuk, Yu.V., Mel'nikov, D.V., et al., New Paroxysmal Phase of the Molodoi Shiveluch Eruption, Kamchatka, February 27, 2005 (Preliminary Report), Vulkanol. Seismol., 2006, no. 1, pp. 16-23.

3. Girina, O.A., Malik, N.A., and Kotenko, L.V., Active Volcanoes on Northern Kurils and Their Activity in 2004-2005, in Materialy ezhegodnoi konferentsii, posvyashchennoi Dnyu vulkanologa (Proc. Annual Conf. Devoted to a Day of Volcanologist), PetropavlovskKamchatskii: IViS DVO RAN, 2005, pp. 79-87.

4. Girina, O.A., Senyukov, S.L., and Nil, K.A., Kamchatka Volcanic Eruption Response Team (KVERT) in 20022004, in Materialy 4-go mezhdunarodnogo soveshchaniya po protsessam $v$ zonakh subduktsii Yaponskoi, Kurilo-Kamchatskoi i Aleutskoi ostrovnykh dug, avgust 2004 (Proc. 4th Int. Conference on Processse in the zones of Subduction of the Japan, Kurils-Kamchatka, and Aleutian Island Arcs), Petropavlovsk-Kamchatskii, 2004, pp. 31-32.

5. Nuzhdaev, A.A., Girina, O.A., and Mel'nikov, D.V., Certain Results of Studying Pyroclastic Deposits of Molodoi Shiveluch Eruptions of February 28 and September 22, 2005, by Ground-Based and Remote Methods, Vestn. KRAUNTs, Nauk. Zeml., 2005, issue 6, pp. 62-66.

6. Kir'yanov, V.Yu., Nil, K.E., Gordeev, E.I., et al., Kamchatka Volcanic Eruption Response Team (KVERT), USG, 2003.

7. Senyukov, S.L., Droznina, S.Ya., Nuzhdina, I.N., et al., Studies of the Kamchatka Volcanoes by Remote Methods in 2005, in Materialy Mezhdunarodnogo simpoziuma po problemam eksplozivnogo vulkanizma (Proc. Int. Symposium on Problems of Explosive Volcanism), Petropavlovsk-Kamchatskii, 2006, pp. 64-75. 